Zsolt KISS*

\title{
MENAS I AFRODYTA. „DEWOCJONALIA" Z SANKTUARIUM ŚWIĘTEGO MENASA
}

Od początków rozprzestrzeniania się chrześcijaństwa miejsca uświęcone działalnością lub pochówkiem świętych stawały się celem pielgrzymek. Pamiątką i świadectwem odbycia pielgrzymki były drobne obrazy i figurki przedstawiające świętego (najlepiej ,podpisane”). Tym sposobem wraz z wiernymi trafiały na tereny obecnych Włoch ${ }^{1}$, Niemiec $^{2}$, Francji ${ }^{3}$ czy nawet Polski ${ }^{4}$ małe gliniane naczynka zwane w nauce, ,ampułkami św. Menasa" ${ }^{\circ}$. Mają one kształt małej manierki z dwoma uszkami. Na jednej lub na obu stronach płaskiego brzuśca odciśnięty jest medalion z postacią świętego między dwoma klęczącymi wielbłądami, często opatrzony napisem "MHNA”. Czasem jeden z medalionów zawiera tylko napis „ЕY $\Lambda$ ОГIA TOY АГIOY MHNA”.

Oczywisty jest związek tych ampułek z wielkim sanktuarium powstałym wokół grobu św. Menasa w Egipcie, na zachód od Aleksandrii, w miejscu obecnie zwanym Abu Mina. Wykopaliska na tym stanowisku prowadził w latach 1905-1907 Karl (Carl) Maria Kaufmann. Prace archeologiczne dostarczyły obfitego plonu ampułek św. Menasa (il. 1) oraz innych wyrobów ceramicznych ${ }^{6}$.

${ }^{*}$ Prof. dr hab. Zsolt Kiss - profesor zwyczajny w Zakładzie Klasycznych Kultur Śródziemnomorskich w Instytucie Kultur Śródziemnomorskich i Orientalnych PAN w Warszawie; zkiss@, iksio.pan.pl.

${ }^{1}$ Np. w Rzymie: W. Kühn - F. Vollbach, Frühchristliche Kunst aus Rom, Essen 1962, 110-116, nr 191-204; w Mediolanie: P. Porta, Una piccola collezione inedita di ampolle di S. Mena conservata a Milano nel Museo di Castello Sforzesco, „Notizie del Chiostro del Monastero Maggiore” 15-18 (1975) 41-52; w Bolonii: P. Porta, Le ampolle inedite di S. Mena conservate al Museo Civico Archeologico di Bologna, „Carrobbio” 6 (1980) 301-310.

2 Por. G. Grimm, Die Zeugnisse ägyptischer Religionund Kunstelemente im römischen Deutschland, Leiden 1969, 128-129, nr 140, pl. 15, 2 (Monachium); s. 237, nr 151 (Trewir); s. 174, nr 70, pl. 15, 3 (Bonn).

${ }^{3}$ Por. C. Metzger, Les ampoules à eulogies du Musée du Louvre, Paris 1981. Ogromna większość z blisko 100 egzemplarzy pochodzi ze zbiorów kościelnych.

${ }^{4}$ Por. B. Cabała, Amputki św. Menasa w zbiorach polskich, „Archeologia” 20 (1969) 107-118.

${ }^{5}$ Por. Z. Kiss, Ampoules coptes, w: The Coptic Encyclopedia, ed. A.S. Atiya, New York 1991, 116-117.

${ }^{6}$ Por. C.M. Kaufmann, Die Menastadt und das Nationalheiligtum der altchristlichen Ägypter in der westalexandrinischen Wüste, Leipzig 1910; tenże, Die heilige Stadt der Wüste, München 1924. 
Co prawda na początku lat 50. XX w. Muzeum Koptyjskie w Kairze prowadziło badania w Abu Mina, ale praktycznie nic nie wiadomo o znaleziskach ${ }^{7}$. Od 1964 r. misja niemiecka, pod kierunkiem Petera Grossmana, wznowiła badania archeologiczne, lecz ukierunkowane na architekturę i budownictwo. Tym samym przez długie lata bazą materiałową do studiów nad ampułkami i innymi zabytkami ceramicznymi z Abu Mina były znaleziska misji Kaufmanna. Większość zabytków jest obecnie przechowywana w Liebighaus we Frankfurcie nad Menem. Ta pokaźna kolekcja (ponad 200 egzemplarzy!) została opublikowana przez Gabriele Kaminski-Menssen ${ }^{8}$. Około 60 egzemplarzy ze zbioru Kaufmanna zawędrowało do Staatliche Museen w Berlinie i zostało opublikowane przez Janette Witt ${ }^{9}$. Część znalezisk z wykopalisk Kaufmanna znajduje się zapewne w Muzeum Grecko-Rzymskim w Aleksandrii, lecz pozostaną nierozpoznane i nieopublikowane.

Kaufmann oparł swoją typologię ampułek na kryterium rozmiaru. Zebrał również świadectwa na temat żywota i kultu św. Menasa oraz źródła jego ikonografii ${ }^{10}$, pozostawiając jednak nieruszone zagadnienia rozwoju i ewolucji schematów ikonograficznych. Obraz wzbogacił się nieco dzięki sondażowi stratygraficznemu przeprowadzonemu przez Polską Misję Archeologiczną na Kôm El-Dikka w Aleksandrii w latach 1967-1968. Znalezione w poszczególnych warstwach tego sondażu blisko 100 ampułek lub ich fragmentów pozwoliło opracować próbę chronologii i zarysować ewolucję tej kategorii zabytków ${ }^{11}$.

Wziąwszy pod uwagę oczywiste powiązanie ampułek z pielgrzymką do sanktuarium św. Menasa, już Kaufmann uważał, że ich modelem była butla pielgrzymia -,,Pilgerflasch”. Wydaje się jednak, że nie chodzi tu tylko o naśladownictwo przedmiotu użytkowego wędrowcy przez pustynię. Tradycja kształtu sięga znacznie dalej i szerzej. W tym samym czasie warsztaty ceramiczne Afryki Północnej rozprowadzały obficie na terenie całego Imperium Rzymskiego podobne butle płaskie ${ }^{12}$. Można sądzić, że rzemieślnicy z Abu Mina mieli styczność z takimi produktami. Jeszcze bliższym źródłem inspiracji były na terenie Egiptu tzw. „butle na Nowy Rok”, małe naczynka rozpowszechnione od okresu faraońskiego po cały okres grecko-rzymski,

\footnotetext{
${ }^{7}$ Por. P. Labib, Fouilles du Musée Copte à Saint-Ménas (première campagne), „Bulletin de l'Institut d'Egypte" 34 (1951-1952) 133-138.

${ }^{8}$ Por. G. Kaminski-Menssen, Bildwerke der Sammlung Kaufmann, Bd. III: Bildwerke aus Ton, Bein und Metall, Kassel 1996, 13-106, pl. 3-63.

${ }^{9}$ Por. J. Witt, Werke der Alltagskultur, Teil 1: Menasampullen, Wiesbaden 2000.

${ }^{10}$ Por. C.M. Kaufmann, Zur Ikonographie der Menas-Ampullen mit besonderer Berücksichtigung der Funde in der Menasstadt nebst einem einführenden Kapitel über die neuentdeckten nubischen und aethiopischen Menastexte, Cairo 1910.

${ }^{11}$ Por. Z. Kiss, Les ampoules de Saint Ménas découvertes à Kôm el-Dikka (1961-1981), Aleksandria V, Warsaw 1989.

${ }^{12}$ Por. J.W. Hayes, Late Roman Pottery. A Catalogue of Roman Fine Wares, London 1972, 185, Form 147, pl. V, 3.
} 
zawierające uświęconą wodę z Nilu ${ }^{13}$. Kształt jest identyczny, a i funkcja przechowanie uświęconej wody - taka sama. Można tu przywołać określenie, jakiego użył Michel Egloff nazywając ampułki św. Menasa „l’article de bazar typique de la Lourdes égyptienne"14.

Misja Kaufmanna odsłoniła w osadzie koło sanktuarium liczne piece, czasem nawet z zawartością, świadczące o pokaźnych rozmiarach produkcji wyrobów ceramicznych ${ }^{15}$. Produkcja obejmowała także różne dzbany i dzbanuszki, które - po dodaniu atramentem napisu „EY $А$ ОГIA MHNA” - stawały się również pojemnikami na wodę ze źródła przy grobie świętego i świadectwem odbycia pielgrzymki (il. 2) ${ }^{16}$.

Podobne przesłanie, wyrażone nie przez napis, lecz przez obraz, odnajdujemy w małych naczynkach w kształcie męskiej głowy. Rozmiar i funkcja pozwalają określić je jako „plastyczne ampułki św. Menasa”. Obficie występują w materiale pochodzącym z misji archeologicznej Kaufmanna ${ }^{17}$, są także poświadczone na polskich wykopaliskach na Kom El-Dikka ${ }^{18}$. Mniej ,jednoznaczne" od ampułek w kształcie butli z dwoma medalionami, są one poza tym rzadkie lub nierozpoznane ${ }^{19}$. Wykończone są ręcznie, w związku z czym występują duże różnice w modelunku i w uzupełnieniu szczegółów, zwłaszcza oczu, polichromią (il. 3-5). Charakterystyczne opracowanie włosów (il. 4) upodabnia tę trójwymiarową głowę do dwuwymiarowego profilu świętego na medalionach niektórych ampułek ${ }^{20}$. Można więc przypuszczać, że naczynka w kształcie głowy miały wyobrażać samego Menasa, potwierdzając w ten sposób (zamiast napisu) pochodzenie z sanktuarium tego świętego.

Schemat artystyczny nie był nowy. Naczynia w kształcie głowy ludzkiej były dobrze znane w ceramice greckiej, choć z predylekcją dla typów etnicznych lub wprost karykaturalnych ${ }^{21}$. Tradycję tę odnaleźć można także w koroplastyce Egiptu grecko-rzymskiego ${ }^{22}$. Oczywiście w wypadku naczynek z Abu

${ }^{13}$ Por. M. Seif El-Din, Die reliefierten hellenistisch-römischen Pilgerflaschen, Caire 2006.

${ }^{14}$ M. Egloff, Kellia: la poterie copte, Genève 1977, 100.

${ }^{15}$ Por. Kaufmann, Die heilige Stadt, s. 197-207, pl. 171.

${ }^{16}$ Por. tamże, pl. 95; Kaminski-Menssen, Bildwerke der Sammlung Kaufmann, III, s. 259-263, nr 112-129.

${ }^{17}$ Por. Kaminski-Menssen, Bildwerke der Sammlung Kaufmann, III, s. 107-138, nr 64-74.

${ }^{18}$ Por. M. Martens, Figurines en Terre-Cuite Coptes. Découvertes á Kôm El-Dikka (Alexandrie), „Bulletin de la Société Archéologique d'Alexandrie” 43 (1975) 67, pl. II D.

${ }^{19} \mathrm{~Np}$. dwa egzemplarze ze zbioru Ustinow w Oslo, choć zakupione w Aleksandrii, uchodzą za wyroby palestyńskie z II w. prz. Chr., zob. I. Skupińska-Løvset, The Ustinow Collection. Terracottas, Oslo 1978, 37, pl. 70; tamże, s. 38, pl. 87.

${ }^{20}$ Por. np. Kaminski-Menssen, Bildwerke der Sammlung Kaufmann, III, nr 144; Witt, Werke der Alltagskultur, Teil 1, nr 54-58; Kiss, Ampoules coptes, s. 133-134.

${ }^{21}$ Por. M.L. Bernhard, Greckie malarstwo wazowe, Warszawa - Kraków 1966, 48, pl. 160; tamże, s. 73, pl. 272.

${ }^{22}$ Por. M. Fjeldhagen, Graeco-Roman Terracottas from Egypt: Catalogue, Ny Carlsberg Glyptotek, Copenhagen 1992, 199-201, nr 201-204. 
Mina karykatura zniknęła, ale podkreślenie elementu etnicznego pozostało. Widoczne dysproporcje i zniekształcenia w fizjonomii należy raczej przypisywać brakowi wykształcenia artystycznego rzemieślników pracujących dla potrzeb handlu pamiątkami z pielgrzymki.

Znaleziska misji Kaufmanna dowodzą, że produkcja pamiątek nie ograniczała się do wyrobów nawiązujących wyraźnie i bezpośrednio do patrona ośrodka pielgrzymkowego. Można się zastanawiać czy istnieje jakaś więź między św. Menasem i licznymi figurkami jeźdźca, odnajdowanymi zarówno w Abu Mina, jak i podczas polskich wykopalisk w Aleksandrii (il. 7-9)23. Modelowane ręcznie, są bardzo różnej jakości, ale posiadają kilka elementów wspólnych. Postać siedząca na koniu jest żołnierzem, o czym świadczą skórzane pasy podtrzymujące broń, oddane polichromią (il. 8). Nie jest to jednak rzymski legionista - zamiast tarczy prostokątnej dzierży on tarczę okragłą, tradycyjnie grecko-macedońską (il. 7), a zamiast hełmu nosi miękką czapkę filcową zwaną „causia” (il. 9). Jest on niewątpliwie późną i marnej jakości odmianą schematu dobrze znanego w koroplastyce Egiptu grecko-rzymskiego - tzw. ,jeźdźca macedońskiego"24. Rzemieślnik z Abu Mina nie brał już pod uwagę specyfiki „etnicznej”, nie dodał też żadnego elementu, który z jeźdźca uczyniłby podobiznę Menasa. Należy więc traktować figurki znalezione w Abu Mina raczej jako pozbawione treści religijnej produkty handlu pamiątkarskiego straganów wokół sanktuarium.

Podobny charakter miały zapewne odnalezione w czasie wykopalisk Kaufmanna figurki zwierząt (il. 6). Wyobrażenia gołębia ${ }^{25}$ należą do repertuaru koroplastyki Egiptu grecko-rzymskiego, a ikonografia wytworów z Abu Mina wiernie powtarza wcześniejsze modele ${ }^{26}$. Co prawda gołąb był ptakiem Afrodyty, ale dawno stracił wszelkie przesłanie religijne. Nie można także stwierdzić, czy w Abu Mina nabrał znaczenia chrześcijańskiego. Znając przebieg translacji zwłok św. Menasa na miejsce słynnego sanktuarium, kuszące byłoby dopatrzyć się aluzji do tego wydarzenia w licznych figurkach wielbłąda znalezionych przez misję Kaufmanna ${ }^{27}$. Takie przesłanie byłoby jednak mało

${ }^{23}$ Por. Kaufmann, Die heilige Stadt, pl. 183; W. Weber, Königliche Museen zu Berlin: Die ägyptisch-griechischen Terrakotten, Berlin 1914, nr 33, pl. II; Martens, Figurines en Terre-Cuite Coptes, s. 58-59, pl. III-VI.

${ }^{24}$ Por. E. Breccia, Terrecotte figurate greche e greco-egizie del Museo di Alessandria, II, Bergamo 1934, nr 635, pl. XXI; E. Bayer-Niemeier, Bildwerke der Sammlung Kaufmann, Band I: GriechischRömische Terrakotten, Melsungen 1988, 218-219, nr 499, pl. 91; F. Dunand, Catalogue des terres cuites gréco-romaines d'Égypte, Musée du Louvre, Paris 1990, 214-215, nr 580 i 583-584; J. Fischer, Griechisch-römische Terrakotten aus Ägypten, Tübingen 1994, 388, nr 998 i 1000-1001, pl. 107-108.

${ }^{25}$ Por. Kaminski-Menssen, Bildwerke der Sammlung Kaufmann, III, s. 156-157, nr 3-14, pl. 75-77.

${ }^{26}$ Por. Dunand, Catalogue des terres cuites, s. 297-208, nr 889-905.

${ }^{27}$ Por. Kaminski-Menssen, Bildwerke der Sammlung Kaufmann, III, s. 160-168, nr 25-64, pl. 82-84. 
czytelne. Bardziej prawdopodobny jest związek tego zwierzęcia z pustynią i z pielgrzymią drogą. Przedstawienie nie zawiera żadnych elementów odnoszących się do sanktuarium i powtarza wcześniejszy schemat z okresu grecko-rzymskiego ${ }^{28}$. Jeszcze bardziej wymowne wśród znalezisk misji Kaufmanna są figurki psa i to wyłącznie jednej rasy: krępego ostrowłosego szpica ${ }^{29}$. Widzimy tu czystą kontynuację tradycji drobnej plastyki Egiptu ptolemejskiego i rzymskiego, w której liczne są identyczne figurki terakotowe, lepszej czy gorszej jakości, przedstawiające takiego $\mathrm{psa}^{30}$. Tak jak w wypadku figurek gołębia można w nich widzieć wyłącznie wytwory ,przemysłu pamiątkarskiego", bez żadnego przesłania religijnego.

Omawiane wyżej przedstawienia oddają w sposób czytelny cechy danego gatunku. Inaczej jest z małymi naczynkami w kształcie gazeli, znalezionymi w Abu Mina ${ }^{31}$ oraz na Kom El-Dikka ${ }^{32}$. Zwierzę stoi na wyprostowanych nogach, korpus służy jako pojemnik na płyn, a poziomy wydłużony pyszczek w kształcie rurki tworzy wylew (il. 10). Często na grzbiecie znajduje się wygięty uchwyt. Modelunek nie oddaje wiernie cech anatomicznych zwierzęcia, jedynie dwa spiczaste różki na głowie zdradzają, że chodzi o gazelę. Czasem jednak różki są splecione w jeden róg ${ }^{33}$. Odchodzenie od realizmu świata zwierzęcego jest także wzmocnione przez polichromię tych figurek - swobodne linie malowane brązową farbą nie podkreślają anatomii, lecz tworzą wzory czysto dekoracyjne. Mamy tu do czynienia z oryginalną kreatywnością rzemiosła z okręgu sanktuarium św. Menasa. Można przypuszczać, że te małe naczynka przeznaczone były do czerpania i zapewne zabrania na pamiątkę wody ze źródła przy grobie świętego. Jednak same naczynka, w przeciwieństwie do ampułek, nie zawierały żadnego odnośnika do Menasa.

Sanktuarium i miasto pielgrzymie rozwijały się wokół postaci jednego świętego - Menasa. Zdumiewające jest więc odnalezienie w trakcie

${ }^{28}$ Por. Weber, Königliche Museen, nr 437, pl. 39; H. Philipp, Terrakotten aus Ägypten, Berlin 1972, 21-22, nr 13, pl. 12; Breccia, Terrecotte figurate, s. 59, pl. CXVI, nr 679; Bayer-Niemeier, Bildwerke der Sammlung Kaufmann, I, s. 243-247, nr 595-602, pl. 104-105; Dunand, Catalogue des terres cuites, s. 279-281, nr 830-837; Fischer, Griechisch-römische Terrakotten, s. 416-417, nr 11151116, pl. 118; M. von Falck, Ägypten. Schätze aus dem Wüstensand. Kunst und Kultur der Christen am Nil, Wiesbaden 1996, 160, nr 131.

${ }^{29}$ Por. Kaminski-Menssen, Bildwerke der Sammlung Kaufmann, III, s. 180-181, nr 119-122, pl. 92.

${ }^{30}$ Por. Weber, Königliche Museen, s. 239-240, nr 424-427, pl. 38; Breccia, Terrecotte figurate, s. 58, pl. CXIII, nr 654-657; Fjeldhagen, Graeco-Roman Terracottas, s. 184-185, nr 183184; Dunand, Catalogue des terres cuites, s. 287-293, nr 861-880; Bayer-Niemeier, Bildwerke der Sammlung Kaufmann, I, s. 252-255, nr 624-643; Fischer, Griechisch-römische Terrakotten, s. 117119, nr 1120-1125, pl. 119.

${ }_{31}$ Por. Kaminski-Menssen, Bildwerke der Sammlung Kaufmann, III, 168-118, nr 62-118, pl. 84-92.

${ }^{32}$ Por. Martens, Figurines en Terre-Cuite Coptes, s. 71-72, pl. VII-VIII.

33 Por. Kaminski-Menssen, Bildwerke der Sammlung Kaufmann, III, s. 146-252; taż, Zur Ikonographie und Ikonologie des Einhorns in Frühchristlicher Zeit, ,Städel-Jahrbuch” 15 (1995) 19-34. 
wykopalisk w Abu Mina ${ }^{34}$, jak i na Kôm El-Dikka ${ }^{35}$, dużej ilości terakotowych figurek kobiecych. Figurki są bardzo uproszczone i niestaranne (il. 11). Kobiety stoją z rękami na biodrach, ubrane w długie, luźne suknie, czasami z sumarycznie zaznaczonymi fałdami. Podobnie jak w przypadku innych wyrobów warsztatów ceramicznych z Abu Mina, pewne elementy stroju są zaznaczone polichromią ${ }^{36}$. Mimo uproszczenia, rozpoznajemy strój noszony przez kobiety na niektórych wcześniejszych figurkach terakotowych Egiptu ${ }^{37}$.

Obecność figurek kobiecych w ośrodku kultu św. Menasa pozostaje trudna do wytłumaczenia. Co prawda warsztaty ceramiczne sanktuarium produkowały niedużą ilość tzw. „ampułek św. Tekli” z przedstawieniem świętej ad bestias (il. 12). Jest ona na tych wyobrażeniach ubrana w podobną długa, luźną suknię jak figurki kobiece, ale to nie wystarcza, aby rozpoznać w nich jej wizerunek. Nie wydaje się więc, aby obecność tych figurek w Abu Mina i produkcja nielicznych ampułek mogła świadczyć o rozbudowanym ośrodku kultu św. Tekli w tym miejscu ${ }^{38}$.

Jeszcze bardziej oddala nas od takiej hipotezy przyjrzenie się głowom tych figurek. O ile opracowanie korpusu jest schematyczne, to głowa, nieproporcjonalnie większa, została oddana $\mathrm{z}$ większą starannością $\mathrm{i}$ różnorodnością (il. 13-14) ${ }^{39}$. Nos jest wymodelowany, wielkie oczy są starannie malowane. Zaznaczona plastycznie jest też fryzura, składająca się z równych wypukłych fal. Taki układ włosów jest wiernym powtórzeniem fryzury kobiecej terakotowych figurek okresu grecko-rzymskiego od II w. naśladującej fryzurę cesarzowej Faustyny Młodszej ${ }^{40}$, ale i wcześniej rozpowszechnionej w wizerunkach Afrodyty ${ }^{41}$. Charakterystyczną fryzurę okala element w kształcie półksiężyca. Najczęściej jest gładki i naśladuje diadem ${ }^{42}$, ale często bywa też chropowaty

${ }^{34}$ Por. Kaufmann, Die heilige Stadt, pl. 180; E. Bayer-Niemeier, Griechisch-römische und koptische Frauenstatuetten im Liebieghaus zu Frankfurt. Ein Beitrag zu paganen Traditionen in der frühchristlichen Kunst Ägyptens, w: Studien zur frühchristlichen Kunst III, hrsg. Koch Guntram, Wiesbaden 1986, 1-27, pl. I; Falck, Ägypten, s. 158, nr 26-27.

${ }^{35}$ Por. Martens, Figurines en Terre-Cuite Coptes, s. 63-64, pl. II.

${ }^{36}$ Por. Bayer-Niemeier, Griechisch-römische und koptische Frauenstatuetten, pl. I, 2-3.

${ }^{37}$ Por. Fischer, Griechisch-römische Terrakotten, s. 355, nr 388, pl. 86.

${ }^{38}$ Por. S. Davis, Pilgrimage and the Cult of Saint Thecla in Late Antique Egypt, w: Pilgrimage and Holy Space in Late Antique Egypt, ed. D. Frankfurter, Leiden 1998, 303-339.

${ }^{39}$ Por. Bayer-Niemeier, Griechisch-römische und koptische Frauenstatuetten, pl. I, 4; Martens, Figurines en Terre-Cuite Coptes, s. 62-63, pl. I.

${ }^{40}$ Por. Fischer, Griechisch-römische Terrakotten, s. 398-400, nr 1032-1042; Bayer-Niemeier, Bildwerke der Sammlung Kaufmann, I, s. 167-1270, nr 329-352, pl. 60-62; M.F. Aubert, Égypte romaine, l'autre Égypte, Marseille 1997, 114, nr 121.

${ }^{41}$ Por. M.O. Jentel, Aphrodite (in peripheria orientali), w: Lexicon Icono- graphicum Mythologiae Classicae, II/1, Zurich 1984, 165, nr 165, pl. 169.

${ }^{42}$ J. Engemann, Das Kreuz auf spätantiken Kopfbedeckungen (Cuculla-Diadem-Maphorion), w: Theologia cruces - signum crucis. Festschrift für Erich Dinkler zum 70. Geburtstag, hrsg. C. Andresen - E. Dinkler - G. Klein, Tübingen 1979, 139-141, pl. 5-7. 
lub wymalowane są na nim kwiaty. I w tym wypadku mamy do czynienia z naśladownictwem koroplastyki grecko-rzymskiego Egiptu - gęsty wieniec kwiatowy charakterystyczny był dla postaci Afrodyty, tancerek czy biesiadników, ogólniej możemy mówić o świątecznym zdobieniu głowy kobiecej33. W Egipcie późnorzymskim wieniec kwiatowy został sprowadzony do wełnianego walca zdobionego paskami lub kwiatami ${ }^{44}$. Właśnie takie przybranie głowy przedstawiają figurki z Abu Mina.

Nie są to więc przedstawienia świętej, lecz zwykłych kobiet z fryzurą i zdobieniem głowy wywodzącym się z wcześniejszej tradycji Egiptu grecko-rzymskiego i być może utrzymującym pewien charakter odświętny. Już Kaufmann był świadom do jakiego stopnia ta kategoria zabytków z Abu Mina ilustruje kontynuację grecko-rzymskich tradycji ikonograficznych w twórczości warsztatów ceramicznych ośrodka kultu św. Menasa ${ }^{45}$. Jego pogląd w pełni podziela Eva Bayer-Niemeier, o czym świadczy podtytuł jej opracowania: Beitrag zu paganen Traditionen in der frühchristlichen Kunst Ägyptens ${ }^{46}$.

Kaufmann zaliczył figurki kobiece nie do kategorii pamiątek z pielgrzymki, lecz do przedmiotów wotywnych. Tę interpretację wydają się wzmacniać odkryte w Abu Mina figurki kobiet z takim uroczystym zdobieniem głowy, trzymających na ręku dziecko (il. 15). Nie jest to jednak przedstawienie matki karmiącej, dziecko stoi na jej ramieniu. Figurki powtarzają dobrze znany w koroplastyce Egiptu grecko-rzymskiego schemat określany jako „Izyda z małym Harpokratesem”, lecz odmienny od Isis lactans. Figurki matki „pokazującej dziecko" mają niewątpliwie charakter wotywny - wyrażają podziękowanie lub prośbę o opiekę. Każe to przypuszczać, że Menas miał też charakter opiekuna kobiet i macierzyństwa.

Zupełnie inny charakter mają odnajdowane w Abu Mina i na Kom El-Dikka nieliczne figurki podkreślające kobiecość czy wprost erotyzm (il. 16). Figurka pokryta jest pobiałą. Kobieta nosi rodzaj spiczastej czapki z dużymi uszami. Rysy twarzy są schematycznie modelowane i silnie zaznaczone brązową farbą. Talia jest zwężona, a wydatny biust zdobiony brązowymi kreskami. Kobieta obiema rękami podkasuje suknię. Podkreślenie biustu i podnoszenie aż do brzucha sukni ma niewątpliwie wymowę erotyczną. Gest ten jest prostym naśladownictwem niektórych przedstawień bogini miłości Afrodyty w typie zwanym anasyrma w koroplastyce grecko-rzymskiego Egiptu ${ }^{47}$.

${ }^{43}$ Breccia, Terrecotte figurate, s. 43, pl. LIX; Bayer-Niemeier, Bildwerke der Sammlung Kaufmann, I, nr 11, pl. 2.

${ }^{44}$ Por. L'Orient romain et byzantin au Louvre, ed. C. Giroire - M.-H. Rutschowscaya - N. Bel - F. Gombert-Meurice, Paris 2012, 124, pl. 88-89.

${ }^{45}$ Por. C.M. Kaufmann, Altchristliche Frauenvotivstatuetten der Menasstadt und ihre paganen Vorbilder, „Byzantinisch-neugriechischen Jahrbücher” 2 (1922) 303-310.

${ }^{46}$ Zob. przyp. 34.

${ }^{47}$ Por. Fischer, Griechisch-römische Terrakotten, s. 332-333, nr 816, pl. 86; Dunand, Catalogue des terres cuites, s. 137-138, nr 362-363; tenże, Religion populaire en Égypte romaine: Les terre- 
Afrodyta odsłania łono, czego na figurce z Abu Mina nie widzimy, ale sens pozostaje ten sam. Figurka charakteryzuje się stylem prawie „ludowym”, wyrażającym się w nadmiarze ekspresji w kształcie i w polichromii.

To samo możemy powiedzieć odnośnie do figurek przedstawiających kobietę nagą (il. 17). Powierzchnia pokryta jest pobiałką, ale obecnie nie widać śladów polichromii. Głowa jest nieproporcjonalnie duża, z rozbudowaną fryzurą. Postać jest naga, z szerokimi biodrami i złączonymi nogami, ręce ma rozpostarte, często zgięte w łokciu i uniesione w geście „orantki”. Podkreślenie anatomii nagiej kobiety zaprzecza jednak sugestii związku z modlitwą. Inspiracją dla tej figurki są również przedstawienia Afrodyty $\mathrm{z}$ repertuaru terakot Egiptu rzymskiego - nagiej, z ramionami wzdłuż ciała i z ciężkim przybraniem głowy ${ }^{48}$. Nawet w sanktuarium św. Menasa widzimy więc przejawy jednoznacznego sławienia kobiecości.

Warsztaty ceramiczne Miasta Menasa wytwarzały zarówno różnego rodzaju pojemniki na wodę ze źródła przy grobie świętego, figurki kobiece dla wyrażenia próśb czy podziękowań dla Menasa, jak i drobne figurki zwierząt, czy wreszcie terakoty o zabarwieniu bardziej jarmarcznym. Rzemieślnicy sięgali do wzorców koroplastyki wcześniejszej, ledwo zmieniając i upraszczając je na miarę swoich umiejętności. Zaopatrywali stragany z pamiątkami, które zawsze powstają w pobliżu centrów pielgrzymkowych.

\section{MENAS AND APHRODITE. “DEVOTIONAL SOUVENIRS" FROM ABU MINA SANCTUARY}

\section{(Summary)}

The article considers the ampullae and figurines produced in the Late Antiquity in the sanctuary of St. Menas in Abu Mina. Their forms and iconography are analised in the context of the earlier traditions of greco-roman art in Egypt, in which they are clearly rooted. Both the ampullae and the figurines can be considered as the manifestation of continuity of long established iconographical types in a new, Christian context.

scuites isiaques du Musée du Caire, Leiden 1979, 186-187, nr 60-61, pl. XXXVII; Falk, Ägypten, s. 153 , nr 119.

${ }^{48}$ Por. Weber, Königliche Museen, s. 216-217, nr 215-216, pl. 21 (= Philipp, Terrakotten aus Ägypten, s. 32, nr 47, pl. 43); Breccia, Terrecotte figurate, s. 17, nr 11-12, pl. IV; Fischer, Griechischrömische Terrakotten, s. 329-333, nr 808-818, pl. 85-86; Bayer-Niemeier, Bildwerke der Sammlung Kaufmann, I, s. 145-147, nr 256-261, pl. 49; Dunand, Catalogue des terres cuites, s. 125-131, nr 327-340; Jentel, Aphrodite, II/1, s. 164-165, nr 265-267. 
Key words: Abu Mina, ampullae of St. Menas, egyptian terracota figurines.

Słowa kluczowe: Abu Mina, ampułki św. Menasa, koroplastyka egipska.

\section{BIBLIOGRAFIA}

Aubert M.F., Égypte romaine, l'autre Égypte, Marseille 1997.

BAyer-Niemeier E., Bildwerke der Sammlung Kaufmann, Band I: Griechisch-Römische Terrakotten, Melsungen 1988.

BAYER-NiemeIER E., Griechisch-römische und koptische Frauenstatuetten im Liebieghaus zu Frankfurt. Ein Beitrag zu paganen Traditionen in der frühchristlichen Kunst Ägyptens, w: Studien zur frühchristlichen Kunst III, hrsg. Koch Guntram, Wiesbaden 1986, $1-27$.

Bernhard M.L., Greckie malarstwo wazowe, Warszawa - Kraków 1966.

Breccia E., Terrecotte figurate greche e greco-egizie del Museo di Alessandria, II, Bergamo 1934.

CabaŁa B., Ampułki św. Menasa w zbiorach polskich, „Archeologia” 20 (1969) 107-118.

Davis S., Pilgrimage and the Cult of Saint Thecla in Late Antique Egypt, w: Pilgrimage and Holy Space in Late Antique Egypt, ed. D. Frankfurter, Leiden 1998, 303-339.

Dunand F., Catalogue des terres cuites gréco-romaines d'Égypte, Musée du Louvre, Paris 1990.

Egloff M., Kellia: la poterie copte, Genève 1977.

Engemann J., Das Kreuz auf spätantiken Kopfbedeckungen (Cuculla-Diadem - Maphorion), w: Theologia cruces - signum crucis. Festschrift für Erich Dinkler zum 70. Geburtstag, hrsg. C. Andresen - E. Dinkler - G. Klein, Tübingen 1979, 137-153.

Falck von M., Ägypten. Schätze aus dem Wüstensand. Kunst und Kultur der Christen am Nil, Wiesbaden 1996.

FISCHER J., Griechisch-römische Terrakotten aus Ägypten, Tübingen 1994.

Fubldhagen M., Graeco-Roman Terracottas from Egypt: Catalogue, Ny Carlsberg Glyptotek, Copenhagen 1992.

Grimm G., Die Zeugnisse ägyptischer Religionund Kunstelemente im römischen Deutschland, Leiden 1969.

Hayes W., Late Roman Pottery. A Catalogue of Roman Fine Wares, London 1972.

JENTEL M.O., Aphrodite (in peripheria orientali), w: Lexicon Icono- graphicum Mythologiae Classicae, II/1, Zurich 1984, 154-166.

Kaminski-Menssen G., Bildwerke der Sammlung Kaufmann, Bd. III: Bildwerke aus Ton, Bein und Metall, Kassel 1996.

Kaminski-Menssen G., Zur Ikonographie und Ikonologie des Einhorns in Frühchristlicher Zeit, ,Städel-Jahrbuch” 15 (1995) 19-34.

Kaufmann C.M., Altchristliche Frauenvotivstatuetten der Menasstadt und ihre paganen Vorbilder, „Byzantinisch-neugriechischen Jahrbücher” 2 (1922) 303-310.

Kaufmann C.M., Die heilige Stadt der Wüste, München 1924.

Kaufmann C.M., Die Menastadt und das Nationalheiligtum der altchristlichen Ägypter in der westalexandrinischen Wüste, Leipzig 1910. 
Kaufmann C.M., Zur Ikonographie der Menas-Ampullen mit besonderer Berücksichtigung der Funde in der Menasstadt nebst einem einführenden Kapitel über die neuentdeckten nubischen und aethiopischen Menastexte, Cairo 1910.

Kiss Z., Ampoules coptes, w: The Coptic Encyclopedia, ed. A.S. Atiya, New York 1991, 116-117.

Kiss Z., Les ampoules de Saint Ménas découvertes à Kôm el-Dikka (1961-1981), Aleksandria V, Warsaw 1989.

KüHn W. - Vollbach F., Frühchristliche Kunst aus Rom, Essen 1962.

LaBiB P., Fouilles du Musée Copte à Saint-Ménas (première campagne), „Bulletin de l'Institut d'Egypte" 34 (1951-1952) 133-138.

Martens M., Figurines en Terre-Cuite Coptes. Découvertes á Kôm El-Dikka (Alexandrie), „Bulletin de la Société Archéologique d'Alexandrie” 43 (1975) 53-77.

Metzger C., Les ampoules à eulogies du Musée du Louvre, Paris 1981.

Philipp H., Terrakotten aus Ägypten, Berlin 1972.

Porta P., Le ampolle inedite di S. Mena conservate al Museo Civico Archeologico di Bologna, „Carrobbio” 6 (1980) 301-310.

Porta P., Una piccola collezione inedita di ampolle di S. Mena conservata a Milano nel Museo di Castello Sforzesco, „Notizie del Chiostro del Monastero Maggiore” 15-18 (1975) 41-52.

SeIF El-Din M., Die reliefierten hellenistisch-römischen Pilgerflaschen, Caire 2006.

Skupińska-Løvset I., The Ustinow Collection. Terracottas, Oslo 1978.

WeBer W., Königliche Museen zu Berlin: Die ägyptisch-griechischen Terrakotten, Berlin 1914.

WiтT J., Werke der Alltagskultur, Teil 1: Menasampullen, Wiesbaden 2000.

\section{ANEKS}

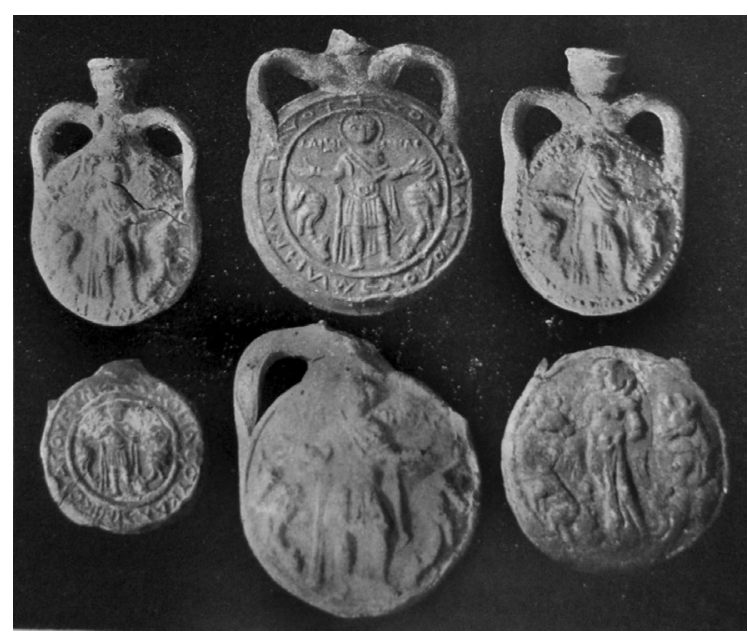

Il. 1. Ampułki św. Menasa, Abu Mina (za: K.M. Kaufmann, Die heilige Stadt der Wüste, München 1924, il. 52). 


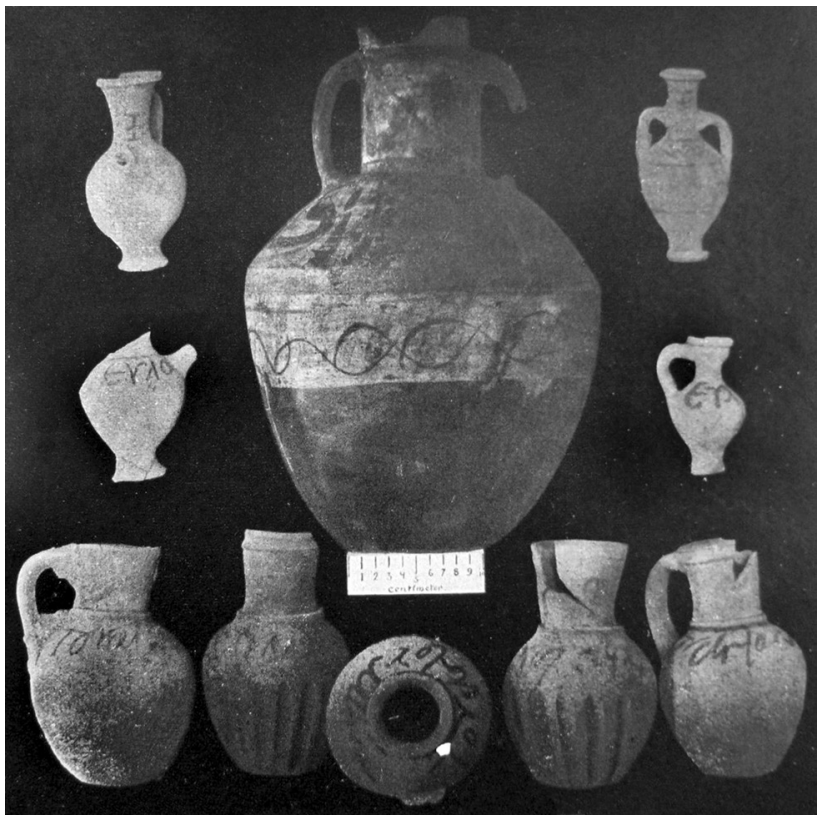

Il. 2. Naczynia na wodę ze źródła przy grobie św. Menasa, Abu Mina (za: Kaufmann, Die heilige Stadt, il. 95).

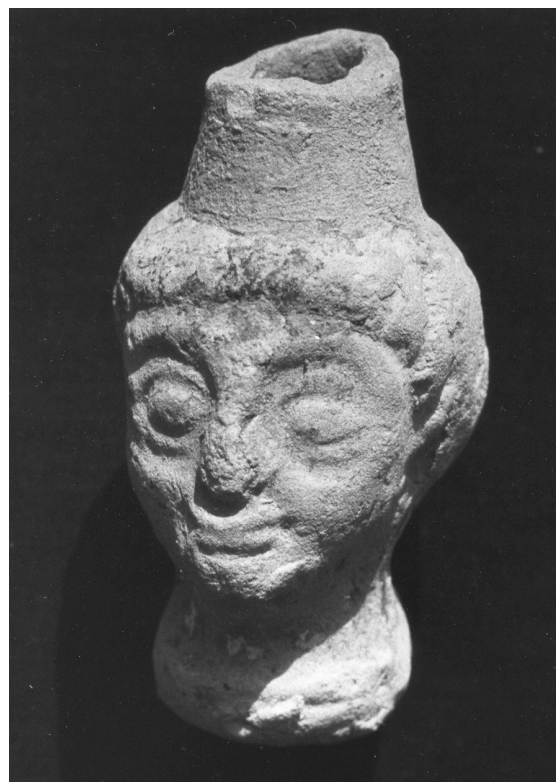

Il. 3. Naczynko w kształcie głowy św. Menasa, Kom El-Dikka (archiwum Instytutu Kultur Śródziemnomorskich i Orientalnych Polskiej Akademii Nauk = IKSiO PAN). 


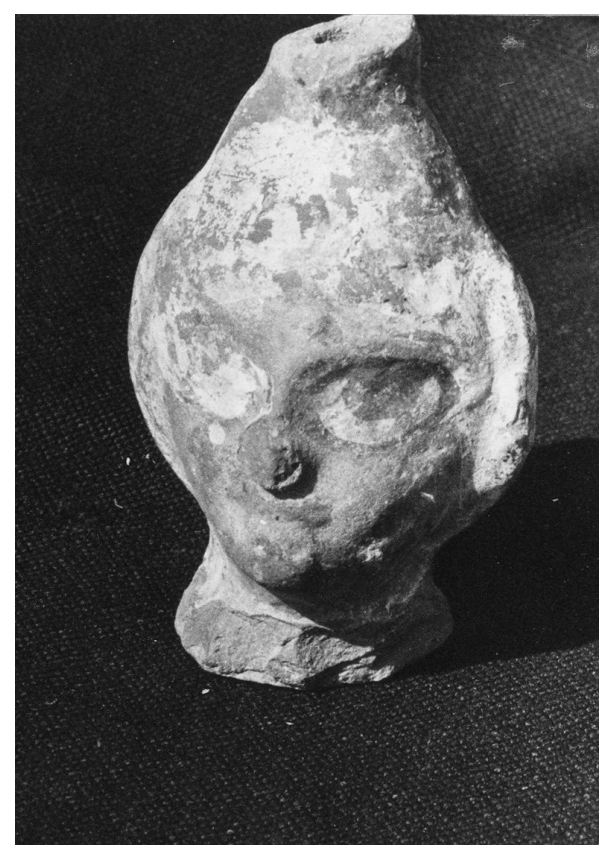

Il. 4. Naczynko w kształcie głowy św. Menasa, Kom El-Dikka (archiwum IKSiO PAN).
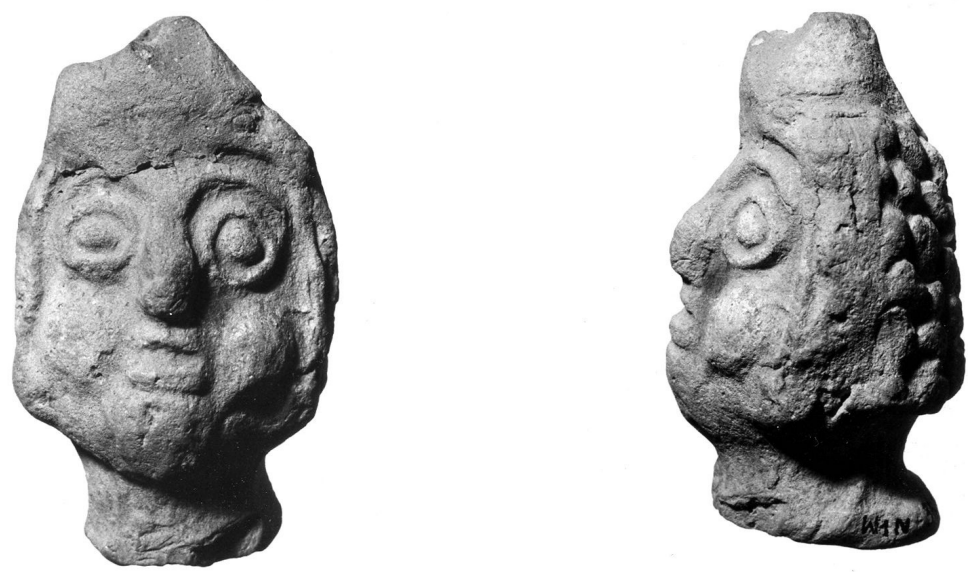

Il. 5. Naczynko w kształcie głowy św. Menasa, Kom El-Dikka (archiwum IKSiO PAN). 


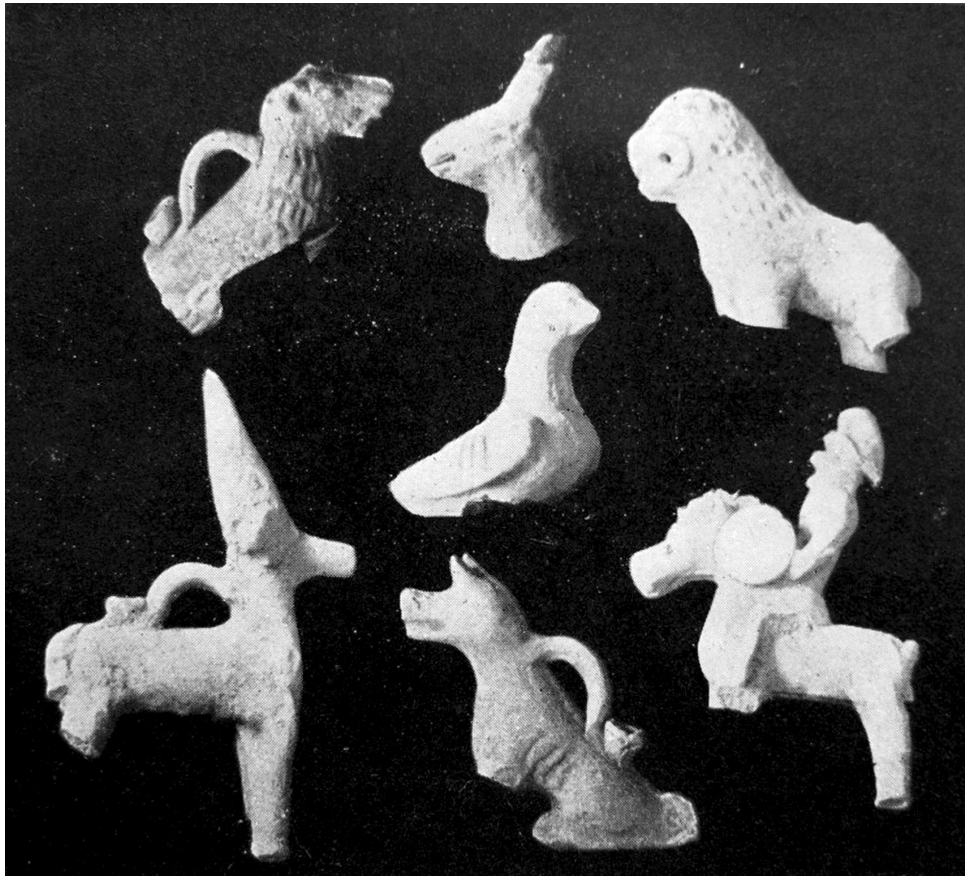

Il. 6. Figurki i naczynka w kształcie gołębia, wielbłąda, psa, gazeli i jeźdźca, Abu Mina (za: Kaufmann, Die heilige Stadt, il. 183).

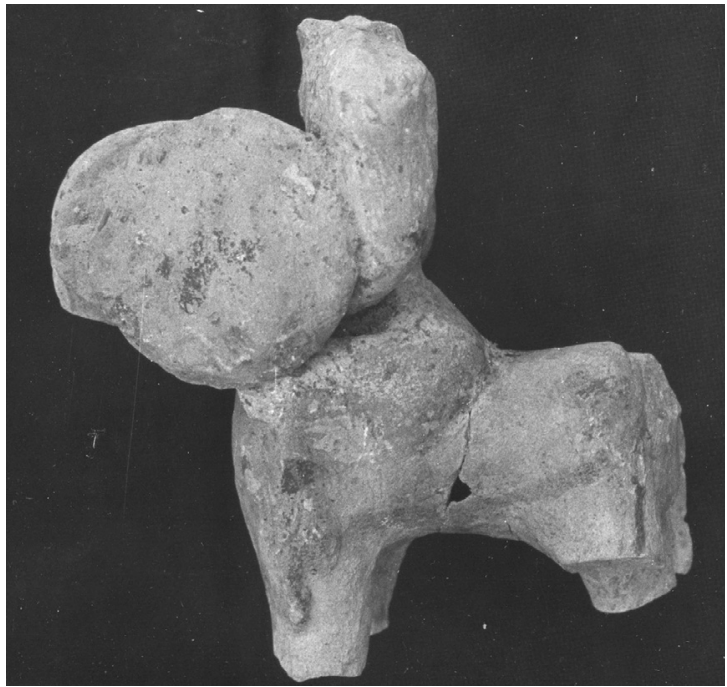

Il. 7. Jeździec, Kom El-Dikka (archiwum IKSiO PAN). 


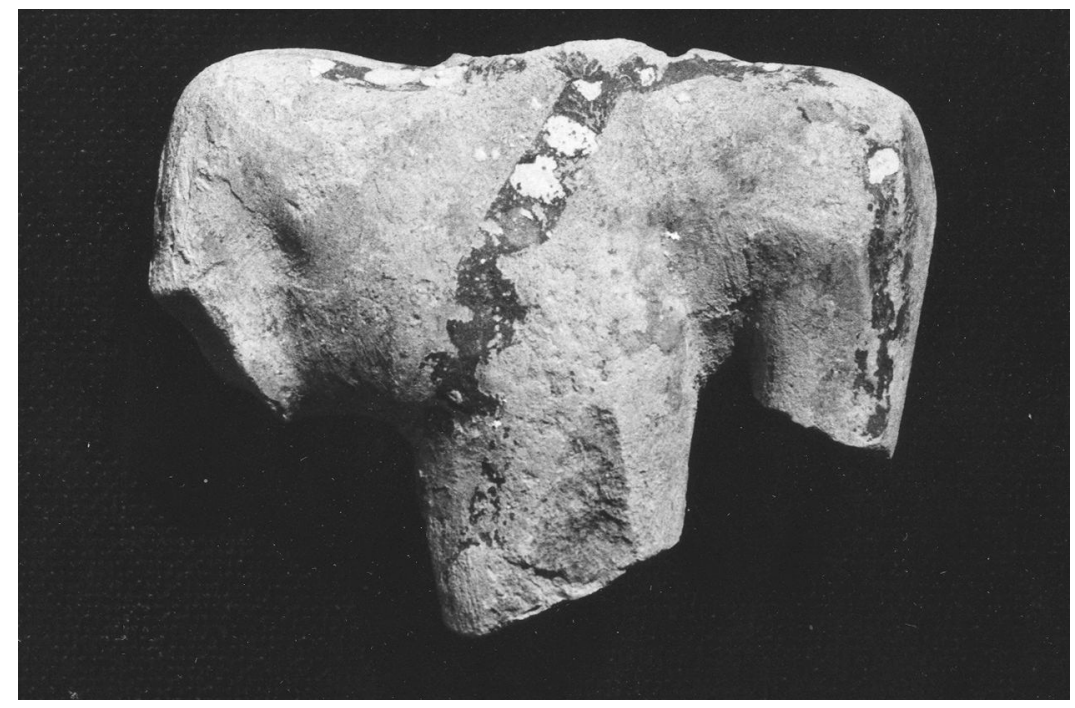

Il. 8. Tors jeźdźca, Kom El-Dikka (archiwum IKSiO PAN).
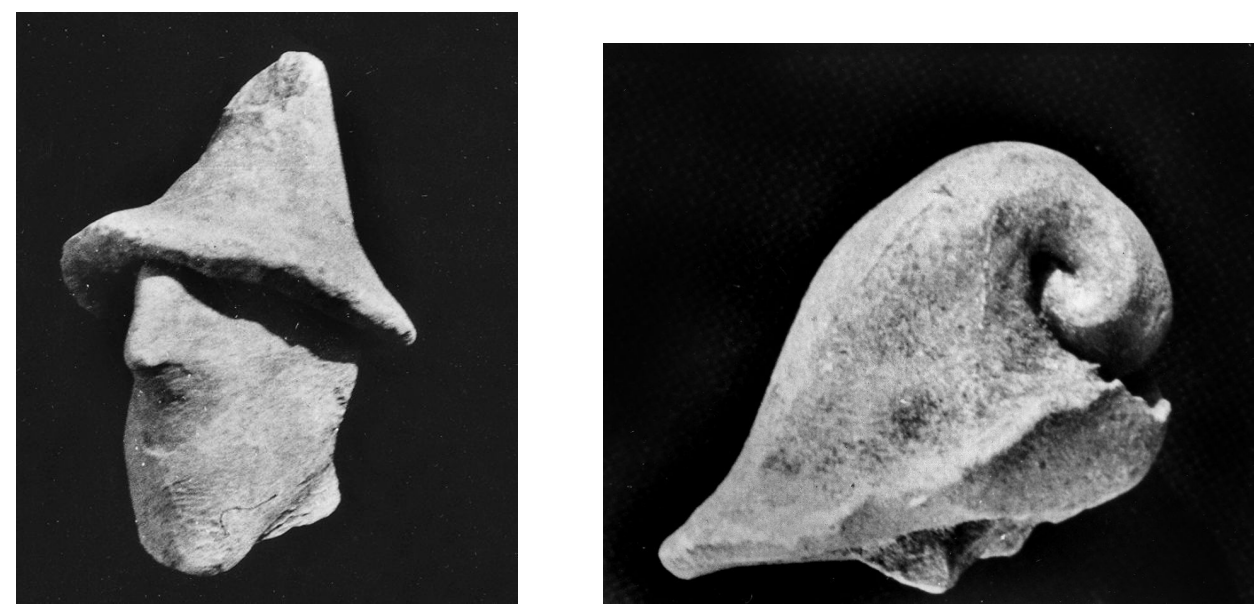

Il. 9. Czapka jeźdźca, Kom El-Dikka (archiwum IKSiO PAN). 


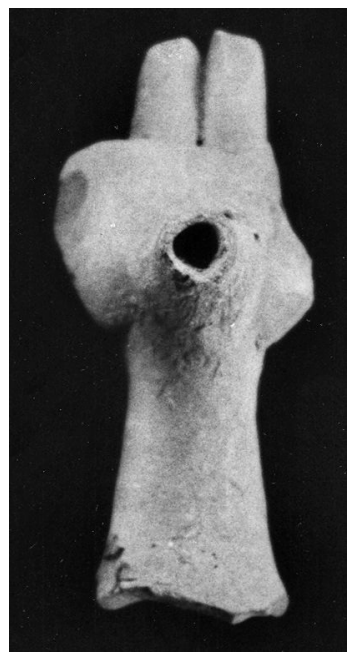

Il. 10. Głowa gazeli - wylew naczynka, Kom el-Dikka (archiwum IKSiO PAN).

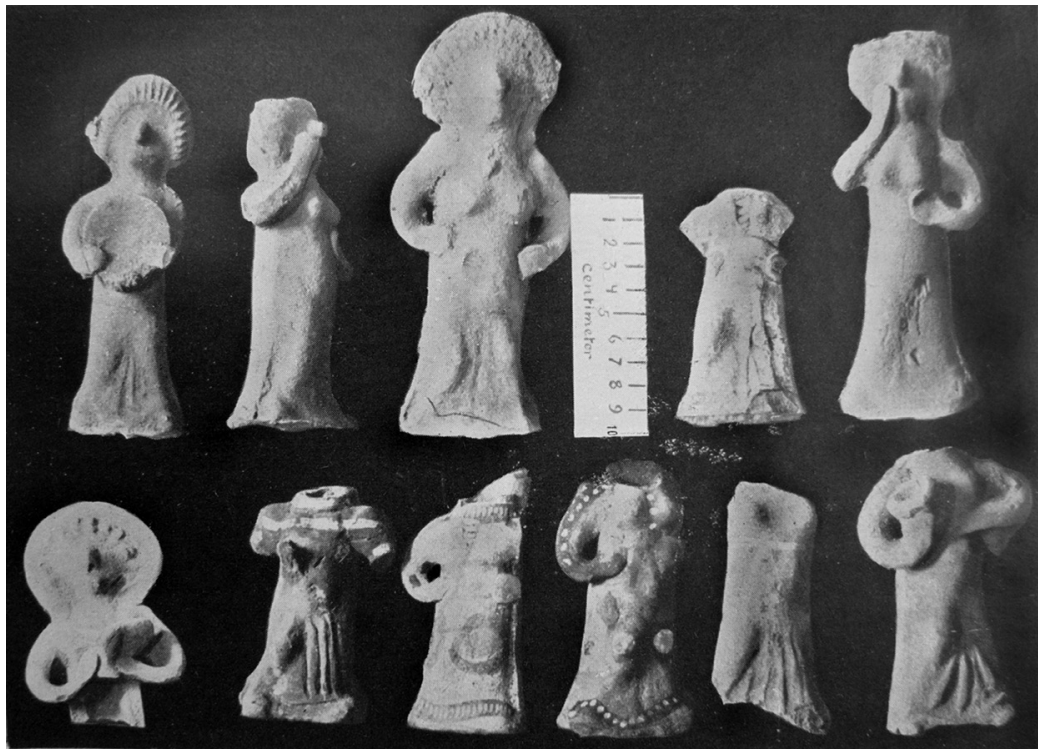

Il. 11. Figurki kobiece, Abu Mina (za: Kaufmann, Die heilige Stadt, il. 180). 


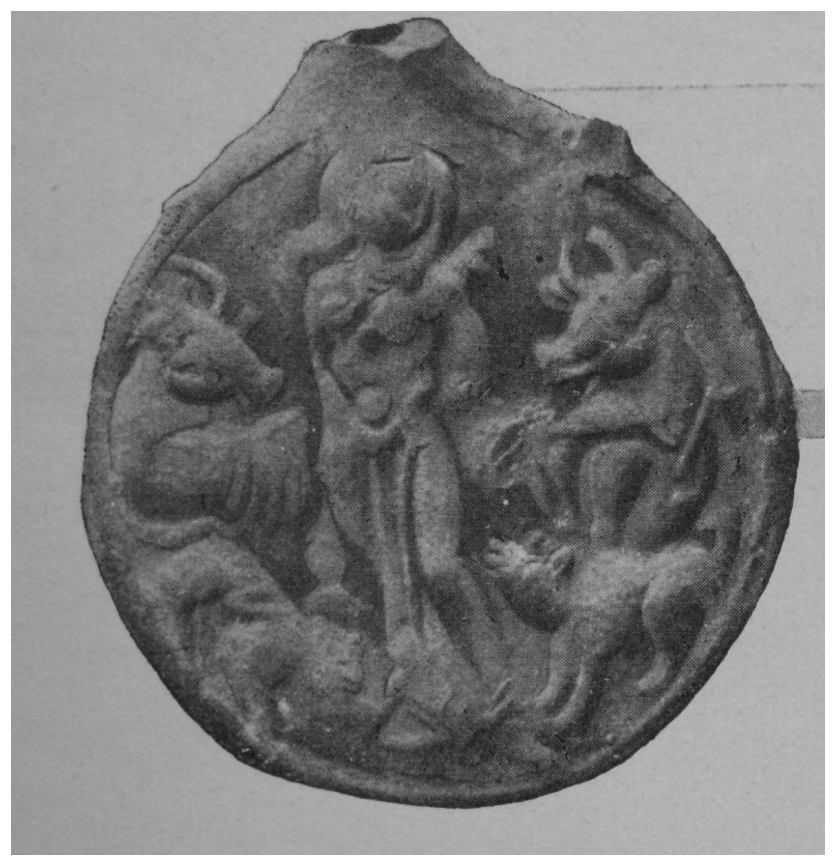

Il. 12. Ampułka św. Tekli, Abu Mina (za: Kaufmann, Die heilige Stadt, il. 62).
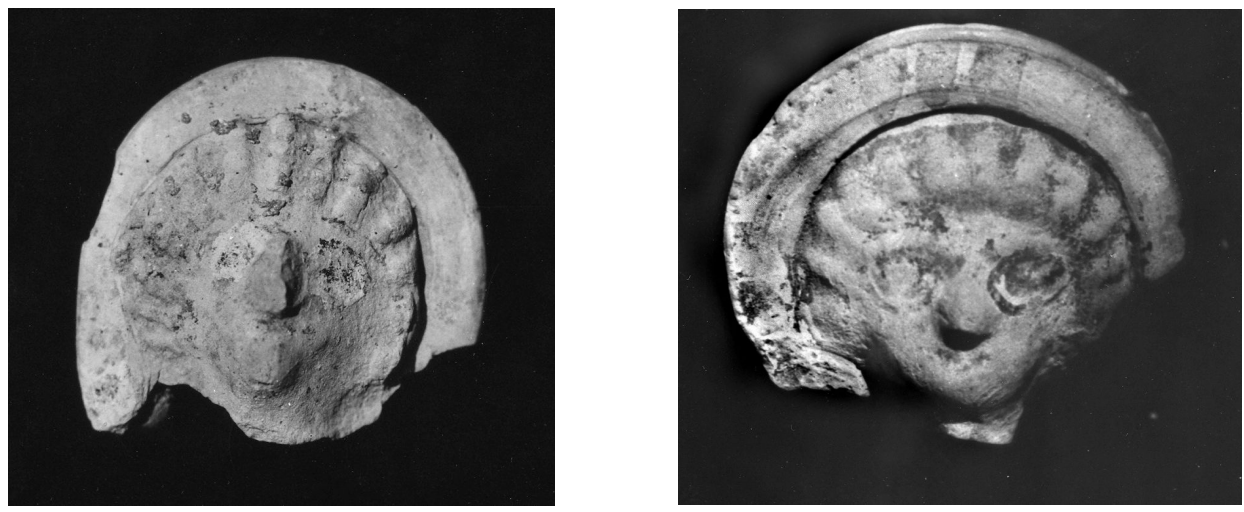

Il. 13. Głowa kobieca, Kom El-Dikka (archiwum IKSiO PAN). 


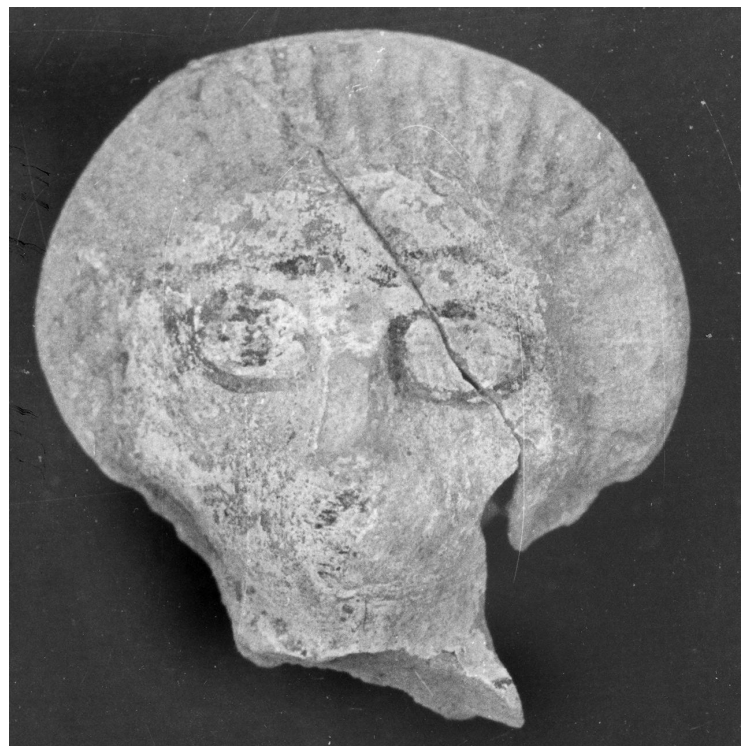

Il. 14. Głowa kobieca, Kom El-Dikka (archiwum (IKSiO PAN).

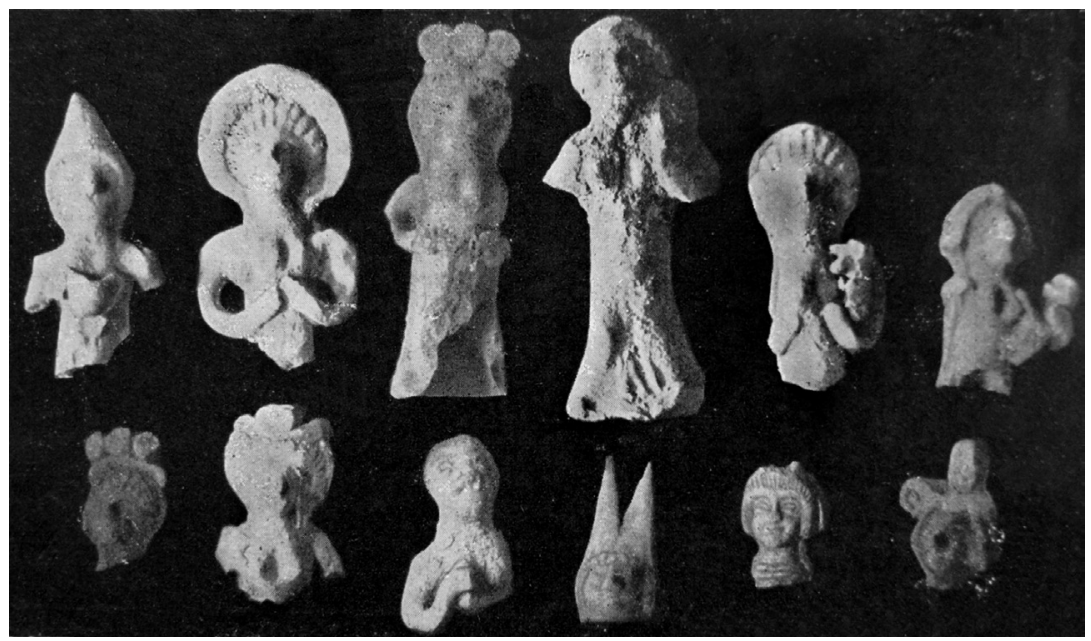

Il. 15. Figurki kobiece z dzieckiem, Abu Mina (za: Kaufmann, Die heilige Stadt, il. 181). 


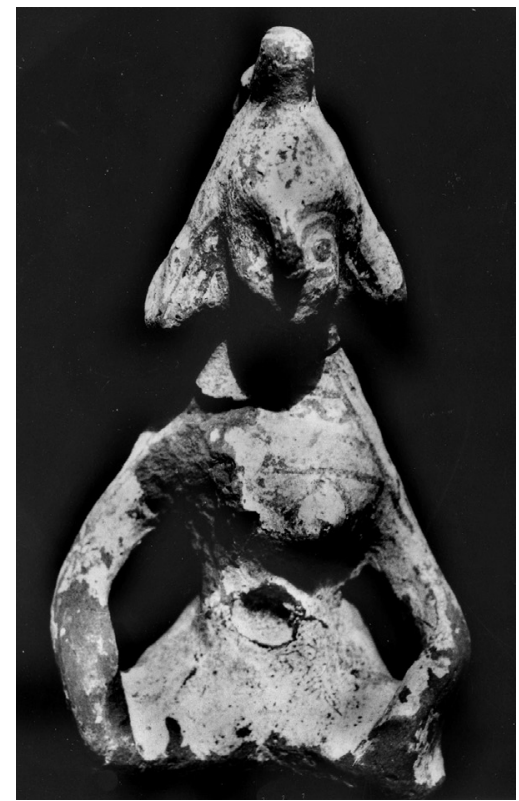

Il. 16. Figurka kobieca, Kom El-Dikka (archiwum (IKSiO PAN).

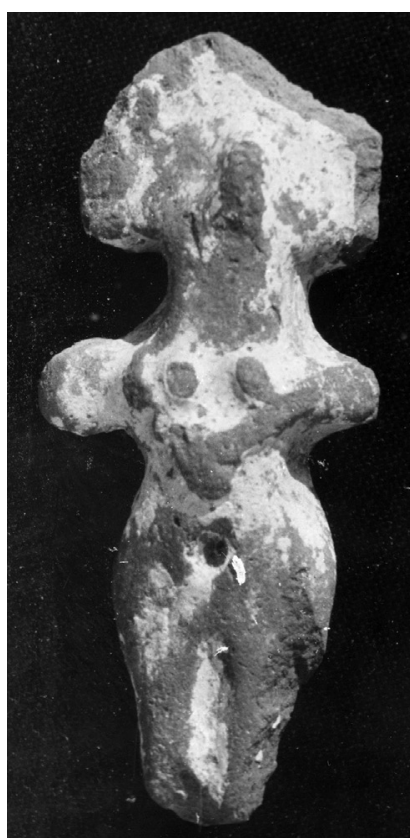

Il. 17. Figurka kobieca, Kom El-Dikka (archiwum (IKSiO PAN). 